\title{
Analisis Faktor-Faktor Penerimaan Sistem Informasi Aliran Barang Dengan Menggunakan Model TAM (Technology Acceptance Model)
}

\author{
Andri Wijaya, Sistem Informasi, Universitas Katolik Musi Charitas
}

\begin{abstract}
Abstrak - Pada era globalisasi saat ini perkembangan teknologi informasi sudah sangat pesat. Salah satu penggunaan teknologi informasi dan sistem informasi pada bidang bisnis distibutor alat-alat kesehatan yaitu diterapkannya sistem informasi dan teknologi informasi yang berfungsi untuk memantau dan memonitoring peredaran barang dan keberadaan barang. Sistem informasi tersebut sudah diimplementasikan pada perusahaan yang menjadi distributor alat-alat kesehatan di kota Palembang dalam kurun waktu 3 (Tiga) tahun. Maka dari itu penulis akan melanjutkan dari penelitian sebelumnya untuk menemukan faktor-faktor yang mempengaruhi penerimaan teknologi dan sistem informasi tersebut dengan menggunakan model TAM (Technology Acceptance Model) dan didasarkan bahwa pengguna sistem cenderung akan menggunakan sistem apabila sistem tersebut mudah digunakan dan bermanfaat baginya. Maka dari itu setelah melakukan penelitian ini menghasilkan bahwa variabel-variabel yang dimiliki oleh model TAM yaitu variabel perceived usefulness dan perceived easy of use secara parsial (sendiri-sendiri) mempengaruhi pengguna dalam menggunakan sistem informasi tersebut begitu juga kedua variabel tersebut secara simultan berpengaruh juga. Dengan hasil tersebut dapat disimpulkan bahwa sistem informasi aliran barang yang digunakan sudah cukup memenuhi beberapa prinsip-prinsip sistem informasi yang baik yaitu mudah digunakan dan bermanfaat.
\end{abstract}

Kata Kunci- Sistem Informasi, technology acceptance model, TAM, IoT

\footnotetext{
Abstract - In the current era of globalization, the development of information technology has been very rapid. One of the uses of information technology and information systems in the business sector of distribution of medical devices is the application of information systems and information technology that functions to monitor and monitor the circulation of goods and the presence of goods. The information system has been implemented in companies that have been distributors of medical devices in the city of Palembang within 3 (three) years. Therefore the authors will continue from previous research to find factors that influence the acceptance of technology and information systems using the TAM (Technology Acceptance Model) model and are based that system users tend to use the system if the system is easy to use and beneficial to it. Therefore, after conducting this research, it is found that the variables owned by the TAM model, namely the variable perceived usefulness and perceived easy of use partially (individually) affect the user in using the information system as well as the two variables simultaneously influential as well. With these results it can be concluded that the information flow system used is sufficient to meet several principles of a good information system that is easy to use and useful.
}

Index Information System, technology acceptance model, TAM, IoT

\section{Pendahuluan}

Pada era globalisasi saat ini perkembangan teknologi informasi sudah sangat pesat. Penggunaan teknologi informasi dan sistem informasi pada semua bidang sudah menjadi kebutuhan khususnya pada saat ini dunia industri sudah memasuki Industri 4.0. Industri 4.0 adalah nama tren otomasi dan pertukaran data terkini dalam teknologi pabrik, istilah ini mencakup sistem cyber-fisik, internet untuk segala (IoT), komputasi awan dan komputasi kognitif [1]. Dengan perkembangan tersebut menyebabkan perubahan sistem dalam suatu organisasi yang berdampak pada cara kerja untuk mencapai kemajuan pekerjaan. Teknologi informasi diterapkan untuk pengelolaan pekerjaan karena daya efektifitas dan efisiensi pekerjaan yang akhirnya meningkatkan keuntungan baik secara finansial maupun jaringan [2].

Perkembangan sistem informasi yang semula tanpa adanya teknologi menjadi berbasis teknologi informasi dengan menggunakan berbagai aplikasi, telah melahirkan sikap penerimaan atau penolakan dari sisi user dalam proses penggunaannya. Dalam kerangka manajemen hubungan pelanggan, sistem informasi yang penggunaannya relatif diterima oleh pengguna (pelanggan) akan meningkatkan nilai layanan yang diberikan perusahaan di mata pelanggannya. Oleh karenanya perlu diketahui bagaimana sikap dan perilaku yang dirasakan user terhadap sistem informasi yang digunakan.

Maka dari itu pada penelitian ini akan berisikan tentang kajian perilaku (user) terhadap penggunaan sistem informasi aliran barang. Sistem informasi aliran barang merupakan hasil dari penelitian sebelumnya yang dilakukan oleh Andri Wijaya pada tahun 2016 dengan mengambil judul Penerapan Sistem Informasi Aliran Barang Pada Pendistribusian Alat-Alat Kesehatan [3]. Pada penelitian tersebut menghasilkan sistem dan teknologi informasi yang sampai saat ini masih digunakan pada salah satu perusahaan distibutor alat kesehatan di kota Palembang.

Penelitian ini menggunakan kerangka pemikiran yang mengadopsi model Technology Acceptance Model (TAM). Penggunaan model TAM didasarkan bahwa sejauh ini TAM merupakan sebuah konsep yang dianggap paling baik dalam menjelaskan perilaku user terhadap teknologi informasi baru 
dan TAM secara empiris terbukti menjelaskan 40\% usage intensions dan behavior. Secara teoritis dan praktis TAM merupakan model yang dianggap paling tepat dalam menjelaskan bagaimana user menerima sebuah sistem.

\section{STUDI LITERATUR}

\section{A. Kerangka Kerja Penelitian}

Kerangka pikir yang digunakan pada penelitian ini sebagai dasar dalam penyelesaian masalah yang ada pada penelitian ini. Langkah - langkah yang dilakukan pada penelitian ini dapat dilihat pada gambar 1 berikut :

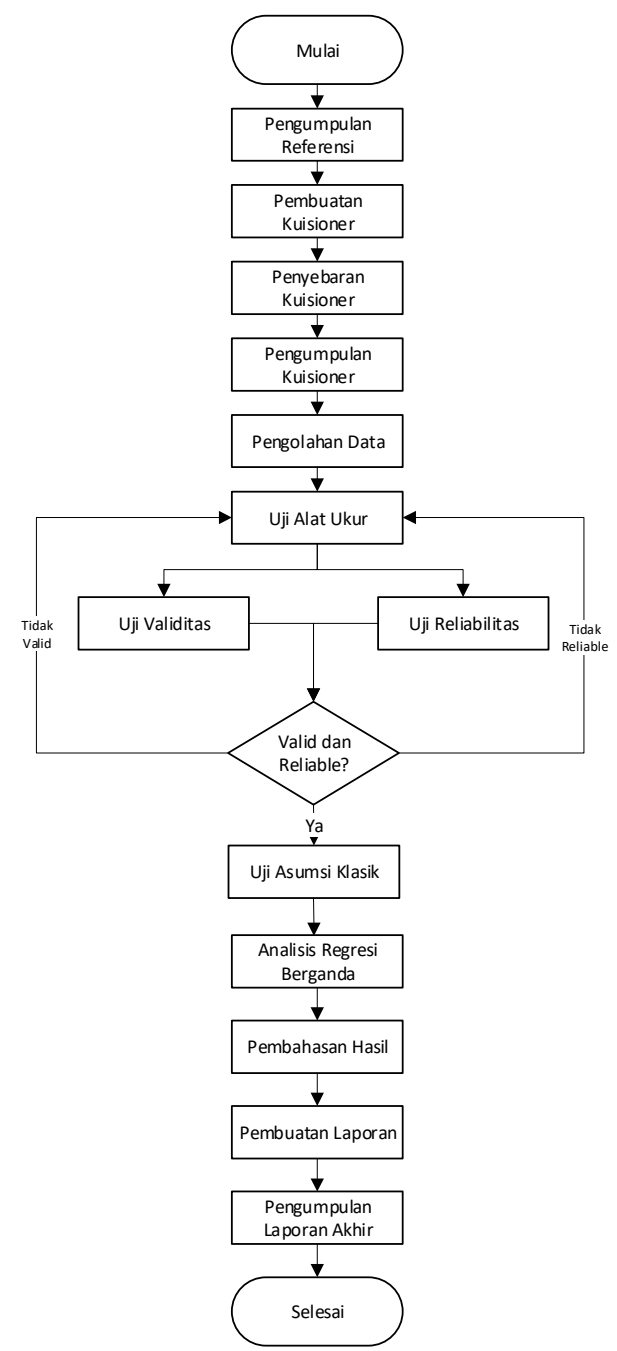

Gambar 1 Kerangka Kerja Penelitian

\section{B. Technology Acceptance Model}

Technology Acceptance Model (TAM) pertama kali diperkenalkan oleh Fred D. Davis pada tahun 1986 adalah adaptasi dari TRA (Theory Of Reason Action) yang dibuat khusus untuk pemodelan penerimaan terhadap sistem informasi dan teknologi informasi. Awalnya TAM dibuat khusus untuk pemodelan adopsi pengguna sistem informasi. Bahwa tujuan utama dari TAM adalah untuk mendirikan dasar penelusuran pengaruh faktor eksternal terhadap kepercayaan, sikap (personalisasi), dan tujuan pengguna computer [4]. Menurut Davis (1989) menjelaskan bahwa tujuan utama TAM adalah untuk memberikan dasar untuk penelusuran pengaruh faktor eksternal terhadap kepercayaan, sikap dan tujuan pengguna. TAM menganggap bahwa 2 keyakinan individual yaitu persepsi manfaat (Perceived Usefulness disingkat PU) diartikan sebagai tingkat di mana seseorang percaya bahwa menggunakan system tertentu dapat meningkatkan kinerjanya, dan kemudahan penggunaan (perceived ease of use, disingkat PEOU) diartikan sebagai tingkat dimana seseorang percaya bahwa menggunakan system tidak diperlukan usaha apapun adalah faktor utama yang mempengaruhi perilaku penerimaan komputer. Ease of use juga berpengaruh pada usefulness yang dapat diartikan bahwa jika seseorang merasa system tersebut mudah digunakan maka system tersebut berguna bagi mereka. Wijaya (2016) menyatakan bahwa TAM mendeskripsikan terdapat dua faktor yang secara dominan mempengaruhi integrasi teknologi. Faktor pertama adalah persepsi pengguna terhadap manfaat teknologi, sedangkan faktor kedua adalah persepsi pengguna terhadap kemudahan penggunaan teknologi. Kedua faktor tersebut mempengaruhi kemauan untuk memanfaatkan teknologi. Selanjutnya kemauan untuk memanfaatkan teknologi akan mempengaruhi penggunaan teknologi yang sesunggunya. Pada umumnya pengguna teknologi akan memiliki persepsi positif terhadap teknologi yang disediakan. Persepsi negatif akan muncul sebagai dampak dari penggunaan teknologi tersebut. Artinya persepsi negatif berkembang setelah pengguna pernah mencoba teknologi tersebut atau pengguna berpengalaman buruh terhadap penggunaan teknologi tersebut. Sehingga model TAM dapat digunakan sebagai dasar untuk menentukan upaya-upaya yang diperlukan untuk mendorong kemauan menggunakan teknologi. Model awal TAM yang dikembangkan oleh Davis (1989) dijelaskan pada gambar 2 di bawah ini.

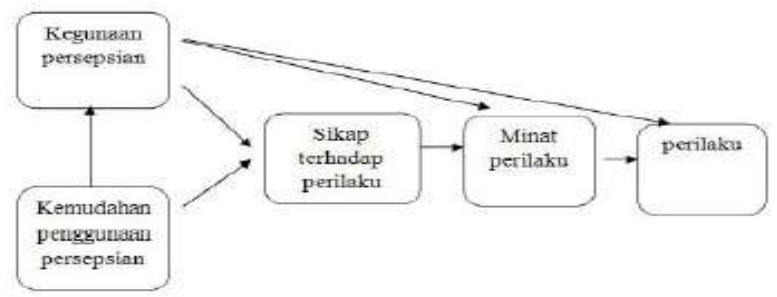

Gambar 2 Model TAM

TAM berargumentasi bahwa penerimaan individu terhadap teknologi informasi ditentukan oleh dua konstruk tersebut.Kegunaan persepsian (perceived usefulness) dan kemudahaan penggunan persepsian (perceived ease of use) keduanya mempunyai pengaruh ke minat perilaku (behavioral intention). Pemakai teknologi akan mempunyai minat menggunakan teknologi (minat perilaku) jika merasa sistem teknologi bermanfaat dan mudah digunakan. Kegunaan persepsian (perceived usefulness) juga mempengaruhi kemudahan penggunaan persepsian (perceived ease of use) tetapi tidak sebaliknya. Pemakai sistem akan menggunakan sistem jika sistem bermanfaat baik sistem itu mudah 
digunakan atau tidak mudah digunakan. Sistem yang sulit digunakan akan tetap digunakan jika pemakai merasa bahwa sistem masih berguna.

\section{Model Penelitian}

Dalam penelitian ini penulis mencoba untuk menggambarkan model penelitian yang mengadopsi dari model dasar Technology Acceptance Model. Berikut gambar 3 dari model penelitian :

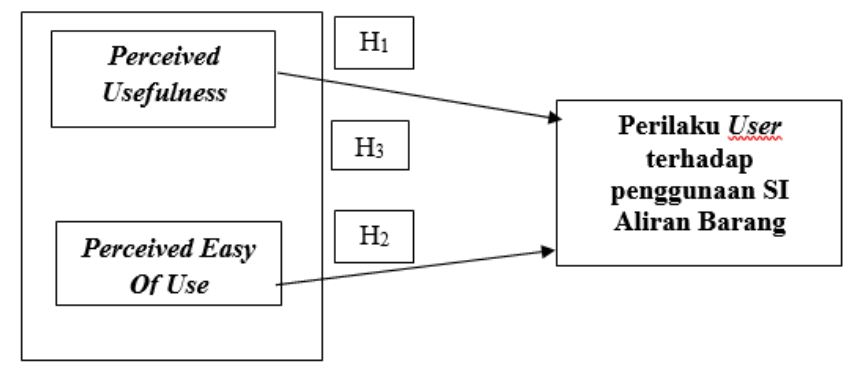

Gambar 3 Model Penelitian

Pada penelitian ini terdapat 3 (tiga) hipotesis yang terbentuk dari model penelitian di atas, hipotesis tersebut adalah :

H1 : Perceived Usefulness berpengaruh signifikan pada perilaku User terhadap penggunaan sistem informasi aliran barang

H2 : Perceived Easy Of Use berpengaruh signifikan pada perilaku User terhadap penggunaan sistem informasi aliran barang

H3 : Perceived Usefulness dan Perceived Easy Of Use secara bersama-sama berpengaruh signifikan pada perilaku User terhadap penggunaan sistem informasi aliran barang

\section{HASIL DAN PEMBAHASAN}

Hasil dari pengumpulan data dan pengolahan data kemudian dari hasil-hasil tersebut akan dilakukan pembahasan secara singkat agar lebih memperjelas hasil yang diperoleh dan memudahkan pembaca untuk memahami hasil penelitian ini.

\section{A. Data Penelitian}

Untuk mendapatkan data yang diperlukan penulis melakukan penyebaran kuisioner seperti yang sudah dijelaskan pada bab sebelumnya. Penyebaran kuisioner dilakukan dengan mendatangi langsung sebanyak 38 responden selama \pm 7 (tujuh) hari untuk mendapatkan data dari mereka. Responden sejumlah 38 orang terdiri dari 3 (cabang) perusahaan dengan formasi seperti pada tabel 1 dibawah ini :

\begin{tabular}{|l|c|c|c|}
\cline { 2 - 4 } \multicolumn{1}{c|}{} & Cabang 1 & Cabang 2 & Cabang 3 \\
\hline Pimpinan & 1 Orang & 1 Orang & 1 Orang \\
\hline Administrasi & 7 Orang & 4 Orang & 4 Orang \\
\hline Kasir & 4 Orang & 3 Orang & 3 Orang \\
\hline Gudang & 4 Orang & 3 Orang & 3 Orang \\
\hline \multicolumn{1}{|c|}{ Total } & 16 Orang & 11 Orang & 11 Orang \\
\hline Total Seluruh & \multicolumn{3}{|c}{ 38 Orang } \\
\hline
\end{tabular}

Kuisioner disebarkan sebanyak 38 lembar dan semua kuisioner kembali. Data-data responden dikelompokan dan dibuatkan profil responden berdasarkan Usia, Jenis Kelamin, divisi kerja, dan lama waktu menggunakan SI aliran barang per hari (dalam jam). Hasil dari pengelompokan profil responden dapat dilihat pada tabel 2 berikut ini :

Tabel 2 Pengelompokan Profil Responden

\begin{tabular}{|c|c|c|l|c|c|}
\hline \multirow{2}{*}{ Divisi Kerja } & $\begin{array}{c}\text { Rata- } \\
\text { rata } \\
\text { Usia }\end{array}$ & \multicolumn{2}{|c|}{ Jenis Kelamin } & $\begin{array}{c}\text { Rata-rata Lama } \\
\text { Menggunakan SI Aliran } \\
\text { Barang (dalam Jam) }\end{array}$ & Jumlah \\
\hline \multirow{2}{*}{ Pimpinan } & $25 \mathrm{Thn}$ & 1 & Laki-laki & 3 Jam & 1 Orang \\
\cline { 2 - 6 } & $41 \mathrm{Thn}$ & 2 & Perempuan & 1 Jam & 2 Orang \\
\hline \multirow{2}{*}{ Administrasi } & $26 \mathrm{Thn}$ & 2 & Laki-laki & 2,5 Jam & 2 Orang \\
\cline { 2 - 6 } & $27 \mathrm{Thn}$ & 13 & Perempuan & $6,3 \mathrm{Jam}$ & 13 Orang \\
\hline \multirow{2}{*}{ Kasir } & $26 \mathrm{Thn}$ & 3 & Laki-laki & 2,3 Jam & 3 Orang \\
\cline { 2 - 6 } & $24 \mathrm{Thn}$ & 7 & Perempuan & 5 Jam & 7 Orang \\
\hline \multirow{2}{*}{ Gudang } & $30 \mathrm{Thn}$ & 7 & Laki-laki & 2 Jam & 7 Orang \\
\cline { 2 - 6 } & $30 \mathrm{Thn}$ & 3 & Perempuan & 5 Jam & 3rang \\
\hline \multicolumn{7}{|c|}{ Total Karyawan } & & Orang \\
\hline
\end{tabular}

\section{B. Hasil Penelitian}

Ini adalah hasil dari penelitian ini yang terdiri dari Uji validitas dan reliabilitas,

1) Uji Validitas dan Reliabilitas

Berikut ini adalah hasil dari uji validitas dan uji reliabilitas data yang sudah diperoleh melalui kuisioner dapat dilihat pada tabel 3 dan 4 berikut ini

Tabel 3 Uji Validitas

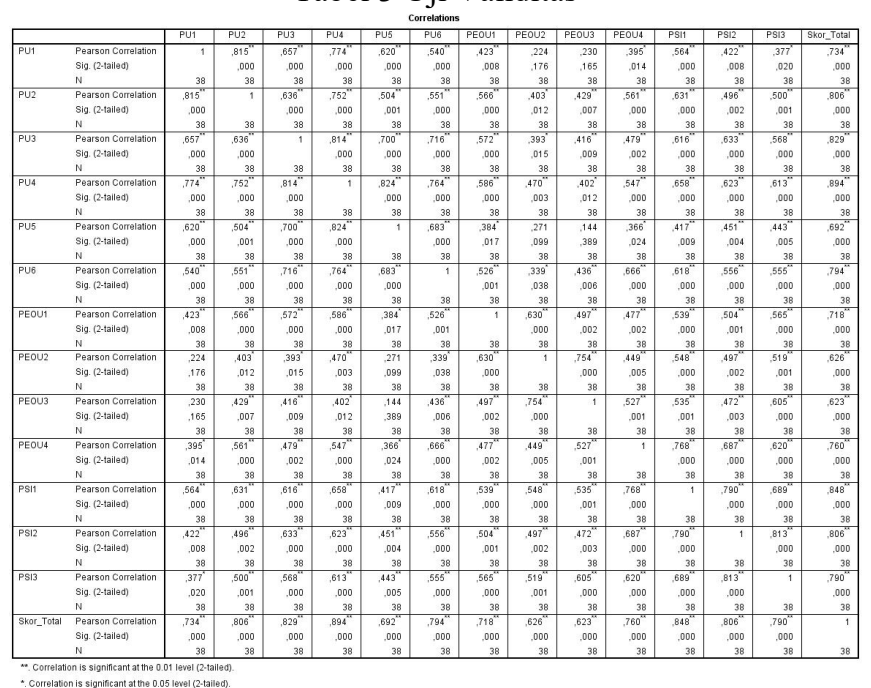

Dari hasil uji validitas diatas peneliti akan mencoba untuk merekapitulasi item-item kuisioner yang digunakan valid atau tidak. Untuk mengetahui hal tersebut pertama penulis sudah 
menentukan nilai $r$ tabel untuk data responden sebanyak 38 dan pada signifikansi 5\%, ditemukan $\mathrm{r}$ tabel sebesar 0,320 didapat dari tabel $r$ tabel yang sudah ada. Selanjutnya peneliti akan membandingkan angka $r$ tabel dengan nilai $r$ hitung yang telah didapat dari hasil pengolahan dengan menggunakan SPSS 22. Dari hasil rekapitulasi dengan membandingkan $r$ tabel dengan $r$ hitung berdasarkan kriteria yang sudah ditetapkan dalam Uji Validitas Pearson Product Moment, jika nilai $\mathrm{r}$ hitung $>\mathrm{r}$ tabel, maka item kuisioner tersebut dinyatakan valid. Dan dari hasil rekapitulasi diatas semua item pada kuisioner dinyatakan valid.

Tabel 4 Uji Reliabilitas
Item-Total Statistics
\begin{tabular}{|l|r|r|r|r|}
\hline & $\begin{array}{c}\text { Scale } \\
\text { Scale Mean if } \\
\text { Item Deleted }\end{array}$ & $\begin{array}{c}\text { Cariance if } \\
\text { Item Deleted }\end{array}$ & $\begin{array}{c}\text { Corrected } \\
\text { Item-Total } \\
\text { Correlation }\end{array}$ & $\begin{array}{c}\text { Cronbach's } \\
\text { Alpha if Item } \\
\text { Deleted }\end{array}$ \\
\hline PU1 & 45,74 & 76,253 &, 665 &, 936 \\
PU2 & 45,74 & 75,713 &, 757 &, 932 \\
PU3 & 45,26 & 77,767 &, 793 &, 930 \\
PU4 & 45,21 & 78,333 &, 873 &, 929 \\
PU5 & 45,16 & 79,974 &, 631 &, 936 \\
PU6 & 45,11 & 81,394 &, 763 &, 932 \\
PEOU1 & 45,34 & 81,204 &, 670 &, 934 \\
PEOU2 & 45,45 & 84,092 &, 576 &, 937 \\
PEOU3 & 45,32 & 83,573 &, 569 &, 937 \\
PEOU4 & 45,24 & 78,186 &, 708 &, 933 \\
PSI1 & 45,53 & 77,067 &, 814 &, 930 \\
PSI2 & 45,45 & 75,713 &, 757 &, 932 \\
PSI3 & 45,68 & 78,006 &, 745 &, 932 \\
\hline
\end{tabular}

Tabel diatas memberikan gambaran tentang nilai statistik untuk ke 13 item pertanyaan dalam kuisioner. Pada kolom Cronbach's Alpha if Item Deleted dalam tabel diketahui nilai Cronbach's Alpha untuk ke 13 item soal adalah > 0,60 maka dapat disimpulkan bahwa ke 13 item pertanyaan kuisioner reliabel.

\section{2) Pengujian Asumsi Klasik}

\section{Uji Normalitas}

Berikut ini adalah hasil dari Uji Normalitas pada data yang sudah diperoleh yang bertujuan untuk menguji apakah data yang digunakan dalam penelitian berdistribusi yang normal atau tidak. Pada hasil uji yang pertama dapat dilihat pada tabel dibawah ini yang menunjukkan bahwa data tidak terdistribusi dengan normal karena angka Asymp. Sig (2-tailed) menunjukkan $<$ dari 0,05 maka data tidak terdistribusi dengan normal dikarenakan ada beberapa data yang ekstrim. Hasil uji dapat dilihat pada tabel 5 dan 6 dibawah ini :

Tabel 5 Hasil Uji Normalitas Tidak Normal

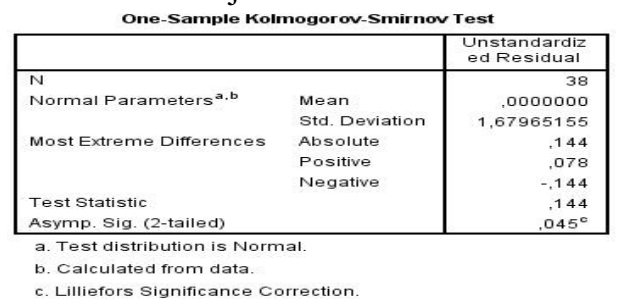

Untuk mengatasi tidak normalan data tersebut penulis melakukan cara dengan menggunakan data outliers dengan mencari terlebih dahulu data-data yang ektrim yang mempengaruhi terjadinya data tidak normal. Seperti pada gambar berikut ini menunjukkan ada data nomor 4 dan data nomor 24 yang menyebabkan data tidak terdistribusi dengan normal.

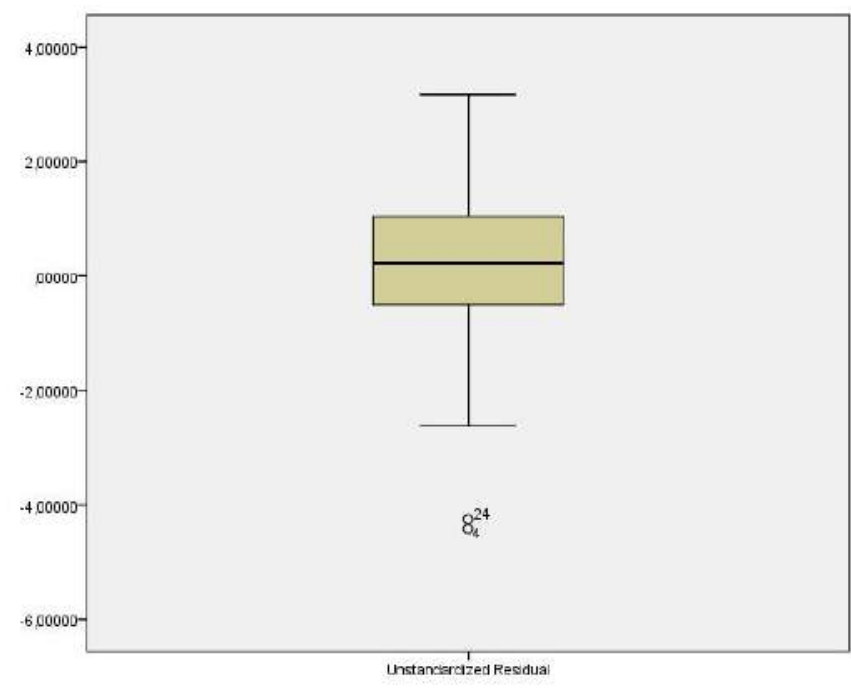

Gambar 4 Data Yang Tidak Normal

Untuk mengatasi data tersebut peneliti melakukan degradasi data untuk data ke 4 dan ke 24. Kemudian melakukan uji normalitas kembali dan menghasilkan seperti pada tabel dibawah ini data sudah terdistribusi dengan normal karena nilai Asymp. Sig (2-tailed) menunjukkan 0,200< dari 0,05, maka data terdistribusi dengan normal.

Tabel 6 Hasil Uji Normalitas Data Normal One-Sample Kolmogorov-Smirnov Test

\begin{tabular}{|c|c|c|}
\hline & & $\begin{array}{l}\text { Unstandardiz } \\
\text { ed Residual }\end{array}$ \\
\hline $\mathrm{N}$ & & 36 \\
\hline \multirow{2}{*}{ Normal Parameters ${ }^{a, b}$} & Mean & .1294556 \\
\hline & Std. Deviation & 1,56307492 \\
\hline \multirow[t]{3}{*}{ Most Extreme Differences } & Absolute & .119 \\
\hline & Positive & .075 \\
\hline & Negative & -.119 \\
\hline Test Statistic & & 119 \\
\hline Asymp. Sig. (2-tailed) & & $200^{c . c}$ \\
\hline
\end{tabular}

\section{Uji Linearitas}

Berikut ini adalah hasil dari uji linearitas yang bertujuan untuk mengetahui dua variabel mempunyai hubungan yang linear secara signifikan atau tidak. Korelasi yang baik seharusnya terdapat hubungan yang linear antara variabel independent dengan variabel dependent. Hasil uji linearitas dapat dilihat pada tabel 7 berikut ini :

Tabel 7 Hasil Uji Linearitas

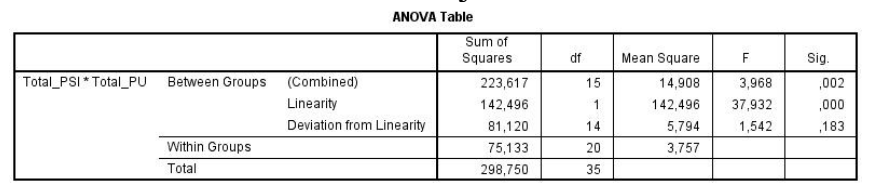


Dari tabel diatas menunjukkan adanya hubungan yang linear dari variabel-variabel yang ada pada penelitian. Kesimpulan tersebut diambil berdasarkan nilai signifikansi (Sig) dari output di atas diperoleh dari nilai Deviation From Linearity Sig adalah 0,183 lebih besar dari 0,05 dan berdasarkan nilai $F$ hitung adalah $1,542<$ dari $\mathrm{F}$ tabel 2,22, karena $\mathrm{F}$ hitung lebih kecil dari nilai $\mathrm{F}$ tabel maka dapat disimpulkan bahwa adanya hubungan linear secara signifikan antara variabel PU dan PEOU dengan variabel PSI.

\section{Uji Multikolinearitas}

Berikut ini hasil dari uji multikolinearitas yang bertujuan untuk menguji model regresi apakah ditemukan adanya korelasi (hubungan erat) antar variabel bebas atau variabel indpendent. Model regresi yang baik seharusnya tidak terjadi korelasi diantara variabel bebas atau tidak terjadi gejala multikolinearitas. Tabel 8 dibawah ini menunjukkan hasil uji nya :

Tabel 8 Hasil Uji Multikolinearitas

\begin{tabular}{|c|c|c|c|c|c|c|c|c|}
\hline \multicolumn{9}{|c|}{ Coefficients $^{a}$} \\
\hline & & \multicolumn{2}{|c|}{ Unstandardized Coefficients } & \multirow{2}{*}{$\begin{array}{c}\begin{array}{c}\text { Standardized } \\
\text { Coefficients }\end{array} \\
\text { Beta }\end{array}$} & \multirow[b]{2}{*}{ t } & \multirow[b]{2}{*}{ Sig. } & \multicolumn{2}{|c|}{ Collinearity Statistics } \\
\hline \multicolumn{2}{|c|}{ Model } & $B$ & Std. Error & & & & Tolerance & VIF \\
\hline \multirow[t]{3}{*}{1} & $\begin{array}{l}\text { (Constant) } \\
\text { (a) }\end{array}$ & $-3,005$ & 1,559 & & $-1,928$ & .062 & & \\
\hline & Total_Pu & .184 & .065 & .326 & 2,813 & .008 & .642 & 1,558 \\
\hline & Total_PEOU & .639 & .122 & 609 & 5,243 & .000 & 642 & 1,558 \\
\hline
\end{tabular}

Dasar dari pengambilan kesimpulan pada uji ini dengan tolerance dan VIF adalah jika nilai tolerance $>0,10$ maka artinya tidak terjadi multikolinearitas pada model regresi begitu sebaliknya jika $<0,10$ maka terjadi multikolinearitas. Dan jika nilai VIF $<10,00$ maka tidak terjadi multikolinearitas pada model regresi dan juga sebaliknya jika nilai VIF $>10,00$ terjadi multikolinearitas pada model regresi. Dari hasil pada tabel diatas menunjukkan nilai tolerance $0,642>0,10$ dan nilai VIF $1,558<10,00$ maka pada model regresi tersebut tidak terjadi multikolinearitas.

\section{Uji Heterokedasitas}

Tabel 9 dibawah ini menunjukkan hasil dari uji heterokedasitas yang bertujuan untuk mengetahui model regresi dalam penelitian apakah bebas dari masalah heterokedasitas. Berikut hasil uji heterokedasitas :

Tabel 9 Hasil Uji Heterokedasitas

\begin{tabular}{|c|c|c|c|c|c|}
\hline \\
\hline & & & Total_PU & Total_PEOU & $\begin{array}{l}\text { Unstandardiz } \\
\text { ed Residual }\end{array}$ \\
\hline \multirow[t]{9}{*}{ Spearman's rho } & \multirow[t]{3}{*}{ Total_PU } & Correlation Coefficient & 1,000 &, $632^{\prime \prime}$ &,- 177 \\
\hline & & Sig. (2-tailed) & & .000 &, 302 \\
\hline & & $\mathrm{N}$ & 36 & 36 & 36 \\
\hline & \multirow[t]{3}{*}{ Total_PEOU } & Correlation Coefficient & $.632^{\prime \prime}$ & 1,000 & -.067 \\
\hline & & Sig. (2-tailed) & .000 & &, 699 \\
\hline & & $\mathrm{N}$ & 36 & 36 & 36 \\
\hline & \multirow[t]{3}{*}{ Unstandardized Residual } & $\begin{array}{l}\text { Correlation Coefficient } \\
\text {. }\end{array}$ & -.177 & -.067 & 1,000 \\
\hline & & Sig. (2-tailed) & .302 & .699 & \\
\hline & & $\mathrm{N}$ & 36 & 36 & 36 \\
\hline
\end{tabular}

Dari hasil output pada tabel diatas diketahui bahwa nilai signifikansi atau Sig (2-talied) variabel PU sebesar 0,32 dan variabel PEOU sebesar 0,699. Karena nilai kedua variabel tersebut lebih besar dari nilai 0,05 sehingga dapat disimpulkan bahwa tidak terdapat masalah atau gejala heterekedasitas dan artinya model regresi yang dipakai untuk penelitian ini layak untuk dilakukan.

\section{Uji Autokorelasi}

Berikut ini adalah tabel 10 hasil dari uji autokorelasi yang bertujuan untuk menguji apakah dalam model regresi linear terdapat korelasi antara kesalahan pengganggu pada periode $\mathrm{t}$ dengan kesalahan pengganggu pada periode t-1 (sebelumnya). Tabel 10 berikut ini menunjukkan hasil uji tersebut :

Tabel 10 Hasil Uji Autokorelasi

Model Summary

\begin{tabular}{|c|c|c|c|c|c|}
\hline Model & $\mathrm{R}$ & R Square & $\begin{array}{c}\text { Adjusted R } \\
\text { Square }\end{array}$ & $\begin{array}{l}\text { Std. Error of } \\
\text { the Estimate }\end{array}$ & $\begin{array}{l}\text { Durbin- } \\
\text { Watson }\end{array}$ \\
\hline & $845^{a}$ & .715 & .697 & 1,607 & 2,4 \\
\hline
\end{tabular}

a. Predictors: (Constant), Total_PEOU, Total_PU

b. Dependent Variable: Total_PSI

Berdasarkan tabel output diatas diketahui nilai Durbin-Watson (d) adalah sebesar 2,485. Selanjutnya nilai ini akan dibandingkan dengan nilai tabel Durbin -Watson pada signifikansi $5 \%$ dengan rumus $(\mathrm{k} ; \mathrm{N})$. Adapun jumlah variabel independen adalah 2 atau " $\mathrm{k} "=2$, sementara jumlah sampel atau "N" = 38, maka $(\mathrm{k} ; \mathrm{N})=(2 ; 38)$. Angka ini kemudian kita lihat pada distibusi nilai tabel Durbin-Watson, maka ditemukan nilai dL sebesar 1,3730 dan dU sebesar 1,5937. Nilai Durbin-Watson (d) sebesar 2,485 > dari batas atas (dU) yakni 1,5937 dan kurang dari (4-dU) 4-1,5937=2,4063. Maka sebagaimana dasar pengambilan keputusan pada DurbinWatson, dapat disimpulkan bahwa nilai d (Durbin-Watson) terletak diantara $\mathrm{dL}$ dan $\mathrm{dU}$ maka tidak menghasilkan kesimpulan yang pasti apakah terjadi gejala autokorelasi atau tidak. Jika demikian maka peneliti menggunakan alternatif lain dengan menggunakan metode uji run test. Berikut hasil uji run test dapat dilihat pada tabel 11 berikut :

Tabel 11 Hasil Uji Run Test

Runs Test

\begin{tabular}{|l|r|}
\hline & $\begin{array}{c}\text { Unstandardiz } \\
\text { ed Residual }\end{array}$ \\
\hline Test Value $^{\text {a }}$ & 10155 \\
Cases < Test Value & 18 \\
Cases >= Test Value & 18 \\
Total Cases & 36 \\
Number of Runs & 17 \\
Z &,- 507 \\
Asymp. Sig. (2-tailed) &, 612 \\
\hline
\end{tabular}

a. Median

Pada uji Run Test dasar pengambilan keputusan yaitu jika nilai Asymp.Sig (2-tailed) lebih kecil $<$ dari 0,05 maka terdapat gejala autokorelasi, sebaliknya jika nilai Asymp.Sig (2-tailed) lebih besar $<$ dari 0,05 maka tidak terdapat gejala autokorelasi. Berdasarkan output dari SPSS pada uji run test diketahui nilai Asymp.Sig (2-tailed) sebesar 0,612 lebih besar dari 0,05 , maka dapat disimpulkan bahwa tidak terdapat gejala atau masalah autokorelasi. Maka dengan demikian pada 
penelitian ini masalah autokorelasi yang tidak dapat diselesaikan dengan Durbin-Watson dapat teratasi dengan uji run test sehingga Analisis Regresi linear dapat dilanjutkan kembali.

\section{Pengujian Regresi Berganda}

Pada tabel dibawah ini menunjukkan hasil dari Analisis Regresi Berganda yang bertujuan untuk menguji hipotesis pada penelitian ini. Pada penelitian ini terdapat 3 hipotesis dimana 2 hipotesis pertama ingin membuktikan pengaruh secara parsial (sendiri-sendiri) dan untuk hipotesis yang terakhir ingin membuktikan pengaruh secara bersama-sama (simultan), maka dari itu kita akan melakukan 2 pengujian yaitu uji t parsial dan uji f simultan. Berikut hasil Uji hipotesis dapat dilihat pada tabel 12 dan 13 dibawah ini :

Tabel 12 Uji t Parsial

Coefficients $^{a}$

\begin{tabular}{|c|c|c|c|c|c|c|}
\hline \multirow[b]{2}{*}{ Model } & & \multicolumn{2}{|c|}{ Unstandardized Coefficients } & \multirow{2}{*}{$\begin{array}{c}\begin{array}{c}\text { Standardized } \\
\text { Coefficients }\end{array} \\
\text { Beta } \\
\end{array}$} & \multirow[b]{2}{*}{$t$} & \multirow[b]{2}{*}{ Sig. } \\
\hline & & $B$ & Std. Error & & & \\
\hline \multirow[t]{3}{*}{1} & (Constant) & $-3,005$ & 1,559 & & $-1,928$ & .062 \\
\hline & Total_PU & 184 & .065 &, 326 & 2,813 &, 008 \\
\hline & Total_PEOU & 639 & .122 & 609 & 5,243 & .000 \\
\hline
\end{tabular}

Dasar pengambilan kesimpulan untuk hipotesis pada penelitian ini pada uji t secara parsial adalah berdasarkan nilai signifikansi (Sig) dan membandingkan antara nilai t hitung dengan $\mathrm{t}$ tabel. Nilai signifikansi < probabilitas 0,05 maka ada pengaruh antara variabel bebas dengan variabel terikat atau hipotesis diterima, jika nilai signifikansi $>$ probabilitas 0,05 maka tidak ada pengaruh variabel bebas dengan variabel terikat atau hipotesis ditolak. Dan untuk perbandingan nilai $t$ hitung dengan $\mathrm{t}$ tabel yaitu jika nilai $\mathrm{t}$ hitung $>\mathrm{t}$ tabel maka ada pengaruh variabel bebas terhadap variabel terikat atau hipotesis diterima, sebaliknya jika nilai $\mathrm{t}$ hitung $<\mathrm{t}$ tabel maka tidak ada pengaruh variabel bebas terhadap variabel terikat atau hipotesis ditolak.

1. Uji Hipotesis Pertama

H1 : Perceived Usefulness (PU) berpengaruh signifikan pada perilaku User terhadap penggunaan 44 ystem informasi aliran barang (PSI)

Berdasarkan nilai signifikansi (Sig) yang didapat dari tabel diatas diketahui nilai signifikansi (Sig) variabel PU adalah sebesar 0,008. Karena nilai Sig. 0,008 $<0,05$ maka dapat disimpulkan bahwa $\mathrm{H} 1$ atau hipotesis pertama diterima, artinya ada pengaruh perceived usefulness terhadap penggunaan sistem informasi aliran barang.

2. Uji Hipotesis Kedua

H2 : Perceived Easy Of Use (PEOU) berpengaruh signifikan pada perilaku User terhadap penggunaan 44ystem informasi aliran barang (PSI).

Berdasarkan nilai signifikansi (Sig) yang didapat dari tabel diatas diketahui nilai signifikansi (Sig) variabel PEOU adalah sebesar 0,00. Karena nilai Sig. 0,000<0,05 maka dapat disimpulkan bahwa $\mathrm{H} 2$ atau hipotesis kedua diterima, artinya ada pengaruh perceived easy of use terhadap penggunaan sistem informasi aliran barang.

3. Uji Hipotesis Ketiga
H3 : Perceived Usefulness (PU) dan Perceived Easy Of Use (PEOU) secara 44ystem44-sama berpengaruh signifikan pada perilaku User terhadap penggunaan 44ystem informasi aliran barang (PSI).

Tabel 13 Uji f Simultan

ANOVA $^{\text {a }}$

\begin{tabular}{|ll|r|r|r|r|l|}
\hline \multicolumn{2}{|l|}{} & \multicolumn{1}{|c|}{$\begin{array}{c}\text { Sum of } \\
\text { Model }\end{array}$} & \multicolumn{1}{c|}{ df } & Mean Square & F & Sig. \\
\hline 1 & Regression & 213,511 & 2 & 106,755 & 41,330 &, $000^{\mathrm{b}}$ \\
& Residual & 85,239 & 33 & 2,583 & & \\
& Total & 298,750 & 35 & & & \\
\hline
\end{tabular}

a. Dependent Variable: Total_PSI

b. Predictors: (Constant), Total_PEOU, Total_PU

Berdasarkan nilai signifikansi (Sig) yang didapat dari tabel diatas diketahui nilai signifikansi (Sig) sebesar 0,00. Karena nilai Sig. $0,000<0,05$ maka dapat disimpulkan bahwa $\mathrm{H} 3$ atau hipotesis ketiga diterima, artinya variabel Perceived Usefulness dan Perceived Easy Of Use secara simultan berpengaruh terhadap perilaku user dalam penggunaan sistem informasi aliran barang.

\section{Pembahasan}

Pembahasan dari hasil analisa dan penarikan kesimpulan pengujian yang telah dilakukan dan melihat literatur-literatur pada penelitian-penelitian terdahulu yang memiliki kesamaan variabel dan metode maka dapat dijelaskan sebagai berikut :

\section{a. Perceived Usefullness (PU)}

Pada hasil pengujian hipotesis variabel Perceived usefullness berpengaruh terhadap perilaku pengguna dalam penggunaan sistem informasi aliran barang. Hasil ini sejalan dengan temuan yang dilakukan oleh Lutfi et al, 2013; Dalimunthe dan Wibisono, 2013; Yulianto, 2011; dan Wijaya, 2015 yang menghasilkan bahwa variabel ini mempunyai pengaruh terhadap perilaku user dalam menggunakan sebuah sistem informasi dengan penjelasan mungkin sebagian besar pengguna sudah terbiasa menggunakan sistem informasi seperti yang sederhana yaitu aplikasi Mic.Office dan aplikasi-aplikasi komersil lainnya sehingga mereka sudah merasakan manfaat yang diberikan oleh sistem informasi itu sendiri. Dan dapat diartikan juga bahwa karyawan mendapatkan manfaat yang sama bahkan bisa lebih ketika mereka menggunakan sistem informasi aliran barang. Responden juga mengatakan sistem informasi aliran barang ini juga dapat meningkatkan efektivitas dalam menyelesaikan tugas yang diberikan pimpinan mereka. Selain itu juga menghemat waktu karena mereka dapat mengerjakan banyak pekerjaan dengan waktu yang singkat. Pernyataan tersebut juga sesuai dengan pendapat Davis.F.D (1989) dan Fathul Wahid (2007) yang mengatakan bahwa perceived usefullness didefenisikan sebagai suatu ukuran dimana penggunaan suatu teknologi dan sistem informasi dipercaya akan mendatangkan manfaat bagi orang yang menggunakannya.

b. Perceived Easy Of Use (PEOU)

Hasil analisa pengujian hipotesis juga menunjukan bahwa variabel Perceived Easy Of Use (PEOU) berpengaruh terhadap perilaku pengguna dalam 
menggunakan sistem informasi aliran barang. Hasil yang diperoleh ini sebagian besar didukung juga oleh banyak penelitian yang dilakukan oleh Lutfi et al, 2013; Dalimunthe dan Wibisono, 2013; Yulianto, 2011; dan Wijaya, 2015. Hal tersebut dapat diartikan bahwa karyawan sebagai pengguna sistem informasi aliran barang dapat merasakan bahwa semua fasilitas, menu dan feature yang disediakan mudah digunakan, mudah diakses sehingga dapat mempermudah mereka dalam menggunakan sistem informasi tersebut. Pernyataan tersebut didukung juga oleh Davis.F.D (1989) dan Fathul Wahid (2007) yang mengatakan bahwa persepsi tentang kemudahan penggunaan sebuah teknologi dan sistem informasi didefenisikan sebagai satu ukuran dimana seseorang percaya bahwa komputer dapat dengan mudah dipahami dan digunakan.

c. Perceived Usefullness dan Perceived Easy Of Use bersama-sama (simultan) mempengaruhi perilaku pengguna dalam menggunakan sistem informasi aliran barang (PSI)

Pada penelitian ini ditemukan bahwa kedua variabel secara bersama-sama (simultan) mempengaruhi perilaku pengguna dalam menggunakan sistem informasi aliran barang. Temuan ini sama seperti halnya dengan penelitian yang dilakukan oleh Agustinus, 2014; dan Yulianto, 2011; dan Wijaya, 2015 mereka menyatakan hasil bahwa persepsi kemudahan dalam penggunaan dan persepsi kemanfatan secara bersama-sama mempengaruhi perilaku pengguna dalam menggunakan teknologi dan sistem informasi. Dan dapat diartikan bahwa para pengguna sistem informasi aliran barang dapat merasakan kemudahan dan kemanfaatan dalam menggunakan dan membantu mereka dalam menyelesaikan pekerjaan-pekerjaan yang diberikan kepada mereka dan mereka merasakan bahwa sistem informasi aliran barang sudah mudah digunakan.

\section{KESIMPULAN}

Rata-rata dari hasil-hasil penelitian terdahulu yang menjadi referensi penelitian ini apabila Variabel perceived Easy of Use dan variabel perceived usefullness secara parsial sudah saling mempengaruhi variabel dependentnya maka secara otomatis variabel-variabel tersebut secara bersama-sama (simultan) juga akan mempengaruhi variabel dependentnya juga.

\section{DAFTAR PUSTAKA}

[1] Hermann, Pentek, Otto, 2016. Design Principles For Industrie 4.0 Scenarios, IEEE, USA.

[2] Mulyani, A., Kurniadi, D., 2015. Analisis Penerimaan Teknologi Student Information Terminal (S-IT) Dengan Menggunakan Technology Acceptance Model (TAM). J. Wawasan Ilm. 7.

[3] Wijaya, Andri, 2015. Penerapan Sistem Informasi Aliran Barang Pada Pendistribusian Alat-Alat Kesehatan. Penelitian Internal. UKMC.Palembang

[4] Davis, F.D, Bagozzi. R.P. \& Warshaw. P.R. (1989). User acceptance of computer technology: a comparison of two theoretical models, Management Science, 35, 982-1003.

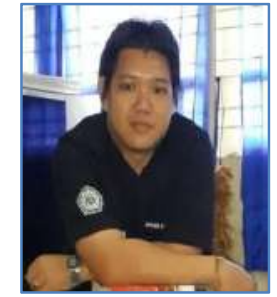

Andri Wijaya, S.Kom., M.T.I lahir di Baturaja pada tanggal 9 bulan Juli tahun 1984. Mendapatkan gelar Sarjana Komputer (S.Kom) pada tahun 2006 dari STMIK Global Informatika MDP, kemudian menyelesaikan pendidikan S2 pada tahun 2011 di Universitas Indonesia Fakultas Ilmu Komputer Program Magister Teknologi Informasi, Jakarta, Indonesia. Saat ini bekerja sebagai Dosen Tetap di Universitas Katolik Musi Charitas, Fakultas Sains dan Teknologi pada program studi Sistem Informasi dan koordinator Jurnal Sistem Informasi (JuSiTik). Adapun bidang keahlian saat ini adalah Analisis Perancangan Sistem Informasi dan Audit Sistem Informasi. 